\title{
IMPROVEMENT OF ADMINISTRATIVE AND LEGAL BASIS OF INSTITUTION OF JUSTICE OF UKRAINE
}

\section{Predmestnikov O. H.}

\section{INTRODUCTION}

The system of justice is an indispensable component of the state apparatus of each state responsible for formulating and implementing its legal policy, asserting the rule of law, ensuring proper functioning of jurisdictional and related entities. Despite the common purpose of its activities the status, composition, competence and organization of the activities of the justice authorities in different countries differ significantly, which, in the first place, is determined by the peculiarities of their legal system, constitutional system, practice and state of construction and social development.

The leading role of the justice bodies of Ukraine in the implementation of state legal policies, improvements to national legislation, and providing the state registration, enforcement of court decisions and enforcement criminal penalties determine the importance of lawful and effective functioning of justice bodies. In this regard, the recent tendency to simplify the system of justice bodies and decentralize their activities, to ensure that they are prioritized and to exercise the citizens' rights is positive.

At the same time, there is still no unified concept of complex development of the status of justice bodies of Ukraine, and the current administrative and legal regulation of their status reveals some inconsistency and fragmentation, their competence is not fully consistent with the structural organization. The reasons for reforming the system of justice include the lack of productivity of their activities, cases of duplication of powers, formalism in the performance of certain tasks, irrational structure, unreasonably large administrative apparatus, shortage of skilled workers, manifestations of corruption and ineffectiveness.

\section{The experience of foreign countries in the organization of the activities of the justice authorities and opportunities for its implementation in Ukraine}

Today, within the framework of modern processes of European integration of Ukraine, democratization, humanization and decentralization of public administration, the system of justice organs of Ukraine is 
undergoing major reorganization changes, which makes the introduction of a positive foreign experience in organizing the activity of justice organs quite important.

Note that some aspects of the organization and operation of justice in other countries have previously been considered by such scientists as R.V. Budetskyy, A.Yu. Guliagin, I.I. Mykultsya, I.Yu. Onopchuk, V.O. Spasenko, A.F. Shestakov and others. At the same time, their scientific works are mainly devoted to the specific issues of organizing the activity of the bodies of justice only in certain foreign countries without their comprehensive comparison with each other, while not comprehensively characterizing the general essential features and differences of the current legal status of the bodies of justice in different countries. Research works of R.V. Budetskyy and I.I. Mykultsya in general are reduced only to citing the structure and basic powers of the Ministry of Justice units in the respective countries without thorough analysis. It is necessary to point out on the use by I.I. Mycultsya of outdated data on the UK justice system (governed not by «the Lord Chancellor's Department, the Home Office, the Attorney-General's and the Solicitor General's Department» ${ }^{1}$ since 2007, but by the relevant Justice Department). In view of this, in the context of improving the status of the justice bodies of Ukraine, the issues of foreign experience of organizing the activity of the justice bodies are also relevant.

First of all, let's note that the main factors that mainly depend on the organization of justice authorities in modern countries are as follows. First, it is political regime (democratic/undemocratic) and government (unitary/federal), on which centralization or decentralized administration in the field of justice, which is carried out only within a single hierarchy of the Ministry of Justice or as the Ministry of Justice and its bodies, as well as by municipal authorities and public institutions. Secondly, it is the degree and nature of the distribution of state power that determines segregation of public administration bodies from the independent/separate bodies of justice, prosecutors, etc. And third, it is succession and legal traditions, which preserves established features and pre-emulation of the existing model of organization of justice (eg, former colonies and dependent territories from the metropolis). It should be emphasized that the use of foreign experience in organizing the activity of justice bodies in Ukraine should also take into account the above and other objective factors.

\footnotetext{
${ }^{1}$ Микульця I. І. Адміністративно-правовий статус органів юстиції України: дис. ... канд. юрид. наук: 12.00.07. Харків, 2014. С. 159-160.
} 
The legal bases for the organization and operation of justice authorities in different countries are usually drawn up by relevant governmental acts and/or heads of state, as well as departmental acts of the Ministry of Justice to regulate their activities and the activities of subordinate bodies. One of the few examples of legislative regulation of the status of the bodies of justice is the Law of the Republic of Kazakhstan dated 18.03.2002 No. 304- $\mathrm{II}^{2}$, which reflects the systematic nature of the bodies of justice, fixing their common tasks, principles of activity, powers, rights and bases of status.

However, in different countries according to the peculiarities of their legal system the degree and content of the regulation of the organization and activity of bodies of Justice differs - if the Resolution of the Government of Moldova dated 03.10.2012 No. $736^{3}$ provides tasks, overall competence and leadership status (which is illustrative - not only Minister's, but also his deputies) of the Ministry of Justice of Moldova, then the Government Decree of France of 09.07.2008, No. 2008-689 outlines the structure in general terms of the Ministry of Justice of France and the main activities of its departments.

The structure of justice bodies in foreign countries is often fixed separately from their competences (for example, the powers of the Main Department of Justice of Minsk regional executive committee are defined by the decision of the regional executive committee from 09.03.2015 No. $199^{4}$, and its structure - by the order of the chairman of the regional executive committee of 25.04.2013, No. $90^{5}$ ). As on us, this approach can adversely affect rationality, unity and coherence of the functional and organizational bases of the activity of justice bodies.

In this regard, the most comprehensive is definitely a complex legislative regulation of organization of activity (status, guarantees, tasks, competences structure, status of leadership, foundations of relations, etc.)

\footnotetext{
${ }^{2}$ Об органах юстиции: закон Республики Казахстан от 18.03.2002 № 304-II. Ведомости Парламента Республики Казахстан. 2002. № 6. Ст. 67.

${ }^{3}$ Об организации и функционировании Министерства юстиции: постановление Правительства Республики Молдова от 03.10.2012 № 736. Monitorul Oficial. 2012. № 212-215. Ст. 799.

${ }^{4}$ Положение о главном управлении юстиции Минского областного исполнительного комитета: решение Минского областного исполнительного комитета от 09.03.2015 № 199/Минский областной исполнительный комітет. URL: http://minobljust.gov.by/ru/ polojenie (дата звернення: 17.12.2016).

5 Структура главного управления юстиции Минского областного исполнительного комитета: распоряжение председателя Минского областного исполнительного комитета от 25.04.2013 № 90p/Минский областной исполнительный комітет. URL: http://minobljust. gov.by/dadvfiles /000127_682722_struktura_gyu.doc (дата звернення: 17.12.2016).
} 
of the bodies of justice that corresponds to their leading role in the state and provides the necessary stability, validity, completeness and consistency of the legal bases of functioning justice agencies.

It should be noted as a positive reference by the Law of Kazakhstan of 18.03.2002 No. 304-II ${ }^{6}$ to the principles of activity of the bodies of justice not only legality, and respect for citizens' rights, publicity and engagement, but also independence from activities of public associations and the unity of the justice system.

Liquidation of district level justice bodies, optimization of competence and the structures of the justice system of Ukraine led to the establishment of a limit number of employees of the Ministry of Justice of Ukraine apparatus and its staff territorial bodies at the level of 1097 and 16675 persons. In turn, the Ministry of Justice of Germany has about 760 employees $^{7}$, about 300 employees $^{8}$ work in the Austrian Ministry of Justice. Accordingly, possible and expedient appears to be the further reducing the number of employees of the Ukrainian justice authorities by depriving them of their inappropriate and irrelevant powers, eliminating duplicate and inefficient units, more efficient staff redeployment, and more.

In foreign countries there are different approaches to defining composition and tasks of systems of justice bodies (governing bodies in the field of justice). For the post-Soviet countries the traditional presence of the Ministry of Justice and its territorial bodies is quite traditional with different degree of separation from courts, prosecutors, bodies of the penitentiary system which are either independent of the Ministry of Justice, or subordinated to it.

In particular in the Republic of Belarus the system of justice bodies respectively to the Resolution of the Council of Ministers of Belarus of October 31, 2001 No. $1605^{9}$ is exactly Ministry of Justice, main departments of justice of regional executive committees and Minsk city executive committees, registries (departments of record of acts of a civil status) of regional executive committees and local administrations

${ }^{6}$ Об органах юстиции: закон Республики Казахстан от 18.03.2002 № 304-II. Ведомости Парламента Республики Казахстан. 2002. № 6. Ст. 67.

7 Aufgaben und Organisation Ministerium/Das Bundesministerium der Justiz und für Verbraucherschutz. URL: http://www.bmjv.de/DE/Ministerium/AufgabenOrganisation/Aufgaben Organisation_node.html (дата звернення: 17.12.2016).

8 Organisation/Die Österreichische Justiz. URL: https://www.justiz.gv.at/web2013/home /ministerium/organisation 8ab4a8a422985de30122a91a6504629f.de.html (дата звернення: 18.12.2016).

${ }^{9}$ Об утверждении Положения о Министерстве юстиции Республики Беларусь: постановление Совета Министров Республики Беларусь от 31.10.2001 № 1605. Национальный реестр правовых актов Республики Беларусь.2001. № 107. Ст. 5/9385. 
of districts in cities, Registry (Palaces) of civil ceremonies of city executive committees, as well as subordinate state organizations (although the latter are not subjects of authorities and therefore should not be considered as bodies of Justice). At the same time, we should note the falseness of referring by I.I. Mycultsya ${ }^{10}$ the district courts and lawyers to the structure of the main justice department of the Minsk City Executive Committee of Belarus.

Therefore, to the peculiarities of the organization of the justice system of Belarus is referred, first of all, the organizational formation of the main departments of justice in the composition of regional executive committees, that results in their double subordination to the respective Regional Executive Committee and at the same time to the Ministry of Justice of the Republic of Belarus (item 1 of Regulation approved by the Decision of the Minsk Regional Executive Committee of 09.03.2015 No. $199^{11}$ ). A similar approach to organizing the activities of territorial justice bodies significantly complicates the management of their activities and urgently requires clear delimitation of organizational and administrative powers of the Ministry of Justice of Belarus and regional executive committees on the main departments of justice. In doing so, the effective functioning of the territorial bodies of justice depends not only on their constructive relations and interaction with local authorities, but also from direct and unconditional submission to the Ministry of Justice of its territorial bodies. Therefore, we do not see an urgent need for direct organizational subordination of the main departments of justice to regional executive committees (or similar to local authorities in Ukraine), which can be completely replaced by the control and accountability of the territorial bodies of justice.

Another specific feature of the organization of the justice system in Belarus is segregation and separation of civil records departments (registries) from territorial bodies of justice acting within the district executive committees with double subordination of the district executive committee and the corresponding department of justice.

This approach to the organization of the activities of the departments of the record of acts of civil status (registries) allows to actually delegate civil registration functions to local authorities (in this case district executive

${ }^{10}$ Микульця I. І. Адміністративно-правовий статус органів юстиції України: дис. ... канд. юрид. наук: 12.00.07. Харків, 2014. С. 161-162.

${ }^{11}$ Положение о главном управлении юстиции Минского областного исполнительного комитета: решение Минского областного испонительного комитета от 09.03.2015 № 199/Минский областной исполнительный комітет. URL: http://minobljust.gov.by/ru/ polojenie (дата звернення: 17.12.2016). 
committees, city executive committees and local district administrations in cities). This, in turn, promotes their responsibility and roles in managing public affairs and unloading of the main departments of justice, while keeping them sufficient organizational and supervisory powers in this area. The above said much corresponds to the modern tendencies of decentralization and demonopolization of activity of the Ukrainian justice authorities, one of the aspects of which is the delegation of powers from state registration to local authorities.

Granting the status of independent bodies of executive power to the bodies of the coercive enforcement of decisions of jurisdictions (as in Israel, the Russian Federation, Finland ${ }^{12 ; 13}$ ) and enforcement agencies with their responsibility to the Ministry of Justice until recently took place in Ukraine. The advantage of this approach is, first of all, includes the discharge of the Ministry of Justice from the rather current issues of enforcement of court decisions and punishments, focusing its activities on general leadership, direction, coordination and control of activities in these areas. The obvious disadvantages include the need for the formation and maintenance of additional management apparatus both nationally and locally. That is why in Ukraine, as in Belarus and Kazakhstan offices and departments of enforcement are separated structural units of the Ministry of Justice and its territorial bodies. In some foreign countries, in particular in Germany, the enforcement authorities may also be subordinated to the court power ${ }^{14}$. Although regardless of the status of enforcement agencies, they always are closely associated with the courts, for example, in the US, the Marshals Service operates under Department of Justice, while functionally focusing on organizational ensuring the activity of the courts and the execution of orders, and procedural decisions of judges. In addition, we believe that given the specific nature of the activities of the authorities the execution of sentences related to the detention of prisoners, their imprisonment, they may be re-socialized and prevented from committing new crimes justifying their allocation to a separate central executive authority or inclusion in the structure of the Ministry of Internal Affairs (as in Belarus and Kazakhstan).

12 Чумак О. О. Практика організації діяльності органів примусового виконання рішень іноземних держав. Форум права. 2011. № 4. C. 814, 815. URL: http://nbuv.gov.ua/j-pdf/FP_ index.htm_2011_4_133.pdf (дата звернення: 21.12.2016).

${ }^{13}$ Сазанов С. В., Могилёва И. Ю. Организация структуры органов принудительного исполнения Финляндской Республики. Юридический мир. 2010. № 5. С. 37-39.

${ }^{14}$ Чумак О. О. Практика організації діяльності органів примусового виконання рішень іноземних держав. Форум права. 2011. № 4. C. 815. URL: http://nbuv.gov.ua/j-pdf/FP_ index.htm_2011_4_133.pdf (дата звернення: 21.12.2016). 
At the same time, the a subordination of the prison system to the Ministry of Justice is a fairly widespread worldwide practice that has been successfully applied, for example, to Austria, Denmark, Poland, USA, France, Czech Republic, Japan and other foreign countries, but it is more about coordination and direction the prison service by the Justice Department, rather than its full integration into the Ministry of Justice.

The Ministry of Justice of the Republic of Moldova does not have its own territorial bodies, which is primarily explained by the relatively small territory of the country and the size of its population. Against this background, something unclear is as for emerging functioning of subordinates to the Ministry of Justice of the Registry and The State Registration Chamber, whose integration into the Ministry of Justice would facilitate the management mechanism and organization of their work. Other bodies that do not subordinate, but only dependent on the Ministry of Justice of the Republic Moldova, are the Department of Prisons, National Inspectorate for Probation and the Agency for the Administration of Courts. In this case, the separated status of the first two bodies, as already indicated, is peculiar by the nature of their activities in organizing the execution of sentences. Like deprivation of Ministry of Justice of Ukraine of powers in the field of judicial administration, so the separation from the Ministry of Justice of Moldova of the Agency for Administration of courts (which provides for the organizational activity of the courts) is quite logically aims at ensuring the independence of the judiciary in the administration of justice.

Within the framework of decentralization, demonopolization and democratization of the state administration in Ukraine there is also an interesting model of decentralized administration in the field of justice in the United States of America, which is manifested in non-proliferation activities of the federal Department of Justice at the state and county levels, as well as at the formation in the states of their own governing bodies in the field of justice. For comparison, The Federal Republic of Germany, as I.I. Mikultsya ${ }^{15}$, accents, the main part of managerial functions (eg prosecutors and executions) relies on the land ministries of justice, but under the control of the federal minister.

In the US, this is primarily determined by the depth of state federalization, particularism of law and separation of the judicial system of the state from the federal judicial system. However, as R.V. Budetskyy points out, Federal US Justice Department and its subordinate bodies are

\footnotetext{
${ }^{15}$ Микульця І. І. Адміністративно-правовий статус органів юстиції України: дис. ... канд. юрид. наук: 12.00.07. Харків, 2014. С. 160.
} 
not legally guaranteed mechanisms for influencing state ${ }^{16}$ authorities, in particular by issuing appropriate ones mandatory for enforcement, control and enforcement penalties in case of violation of such acts.

The selection by H.I. Kobatskaya ${ }^{17}$ of law enforcement (the Ministry of Justice focuses on the judiciary and law enforcement) and general law (limited impact on the judiciary; law enforcement system and concentration on issues of organization, security, control and provision of services in various spheres of social life) types of bodies of Justice deserves attention. According to this approach, the law enforcement type is widespread in the world, the judiciary, though, given the tasks and powers of the judiciary of Ukraine and several other post-Soviet countries, can be attributed exactly to common law type.

It should be emphasized that the activity of the Ministry of Justice is just like any other activity of a governmental body in both Ukraine and foreign countries is closely linked to human rights - by ensuring their proper implementation (for example, the right to legalize non-profit organization), as well as by creating the conditions for compliance, implementation and protection of human rights by other entities (legal executives, notaries, lawyers, court experts, etc.). As for us, the direction of activity of bodies of justice for the realization and protection of the rights and interests of citizens (as well as legal entities and the state) should be determined not so much by the specific task (direction of work), but by one of the key principles of their organization and activity. Human rights, public and state interests should be a common guideline for all aspects of the functioning of justice, while (at least in the post-Soviet countries) specific human rights activities are being carried out by more of their subordinate bodies.

In some foreign countries, registration by the justice authorities of regulatory acts of the government authority is an effective preventive instrument of control over the legitimacy of their rulemaking - both in terms of content and order of the adoption of such acts. By the way, a kind of analogue of the mechanism of registration of legal acts also exists in Germany, where the Ministry of Justice checks compliance with legal techniques and conformity of draft acts of federal ministries and

${ }^{16}$ Будецький Р. Особливості управління юстицією у Сполучених Штатах Америки: організаційно-правовий аспект. Вісник Національної академії правових наук Украӥни. 2014. № 3. C. 162.

${ }^{17}$ Кобацька Х. І. Порівняльно-правова характеристика центральних органів виконавчої влади у сфері юстиції: європейська традиція та вітчизняна практика: автореф. дис. ... канд. юрид. наук: 12.00.01. Київ, 2017. С. 14. 
intergovernmental agreements with national and international law ${ }^{18}$. Registration efficiency of regulations and legal acts is mandatory for entry into force of the acts, and it is also conditioned, for example, by the right of bodies of Justice to submit preference as for violation remedy and to make a motion as for bringing the perpetrators to disciplinary responsibility (Belarus, Kazakhstan). Herewith, like in Ukraine, in the Republic of Moldova, the judicial authorities exercise legal review and registration of acts concerning the rights and legitimate interests of citizens (Resolution of the Government of Moldova dated 03.10.2012 No. $736^{19}$ ).

In European and other foreign countries, it is quite common to charge justice authorities with some functions in the field of judicial administration (first of all, formation of the judicial establishment, the supervision of the work of the courts, the provision of their activities). So, for example, the Ministry of Justice of Germany is directly responsible for the course of justice and oversees the activities of federal courts, takes participation in the preparation of elections to high courts, organizationally and otherwise ensures their functioning ${ }^{20}$. In Belarus, according to Art. 183 of the Judiciary Code and the status of judges of 29.06.2006 No. $139-\mathrm{C}^{21}$ the justice authorities exercise organizational and logistical support of regional, district (city), specialized and military courts, as well as the selection and training of candidates for a judge position (especially the latter being a potential lever to influence judges). In countries of Muslim law, as noted by A.V. Fedkovych ${ }^{22}$, the institutions of justice are also actively involved in the formation of the Judicial establishments and are responsible for organization and operation of the justice system.

The justice authorities in foreign countries as a continuation of their competence in the field of justice may also be entrusted with the power to implement public policy on forensic examination. Such activity is only indirectly relevant to the courts and may be exercised by the judicial

18 Aufgaben und Organisation Ministerium/Das Bundesministerium der Justiz und für Verbraucherschutz. URL: http://www.bmjv.de/DE/Ministerium/AufgabenOrganisation/Aufgaben Organisation_node.html (дата звернення: 17.12.2016).

19 Об организации и функционировании Министерства юстиции: постановление Правительства Республики Молдова от 03.10.2012 № 736. Monitorul Oficial. 2012. №. 212-215. Ст. 799.

20 Aufgaben und Organisation Ministerium/Das Bundesministerium der Justiz und für Verbraucherschutz. URL: http://www.bmjv.de/DE/Ministerium/AufgabenOrganisation/Aufgaben Organisation_node.html (дата звернення: 17.12.2016).

${ }^{21}$ О судоустройстве и статусе судей: кодекс Республики Беларусь от 29.06.2006 № 139-3. Национальный реестр правовых актов Республики Беларусь. 2006. № 107. Ст. 2/1236.

${ }^{22}$ Федькович О. В. Роль органів юстиції в організації та забезпеченні функціонування системи правосуддя: автореф. дис. ... канд. юрид. наук: 12.00.10. Київ, 2007. 19 с. 
authorities irrespective of their judicial administration functions (such as in Ukraine and Kazakhstan, for example). Authority of bodies of forensic justice does not involve direct interference with professional activity of forensic experts, mainly manifesting itself according to Law of Kazakhstan dated 18.03.2002 No. 304- $\mathrm{II}^{23}$ in organization and material and technical support of forensic institutions and licensing of forensic experts. These forensic institutions, without exercising state power authority, are not separate bodies of justice but they are also under the responsibility of the relevant ministry of Justice, for example, the National Center for Forensics at the Ministry of Justice of Moldova. At the same time, the experience of the Republic of Belarus, forensic experts, is quite interesting institutions (including those operating within the Ministry of Justice system) were merged into Independent State Committee of Forensic Expertise (Presidential Decree of Belarus of 04/22/2013, No. 202 ${ }^{24}$ ). As for us, in Ukraine there is a similar grouping under the auspices of different ministries of forensic institutions can facilitate the streamlining of their status and activities, regardless of their subordination to the Ministry justice or self-status.

A modern and progressive line of activity of the justice authorities is organization of providing legal assistance to citizens aimed at creating conditions for the proper exercise and protection of their rights and legitimate interests, security accessibility of legal services and raising public awareness.

Providing legal assistance and compensation for victims of crime, as O.V. Fedkovich ${ }^{25}$ states, is a fairly common task today for the authorities of justice in many European countries of the Romano-German legal family (for example, in Poland).

The common feature of the status of justice bodies in foreign countries is their uniqueness, which is, first and foremost, in the sole control of their system by the Minister of Justice. Therefore, the important role in organizing the activities of the justice authorities plays the subordination as well as the order of appointment and dismissal of the minister Justice. Usually in foreign countries, depending on the form of government, the Minister of Justice reports to the head of government and/or the head

\footnotetext{
${ }^{23}$ Об органах юстиции: закон Республики Казахстан от 18.03.2002 № 304-II. Ведомости Парламента Республики Казахстан. 2002. № 6. Ст. 67.

24 Об образовании Государственного комитета судебных экспертиз Республики Беларусь: указ Президента Республики Беларусь от 22.04.2013 № 202. Национальный реестр правовых актов Республики Беларусь. 2013. Ст. 1/14233.

${ }^{25}$ Федькович О. В. Роль органів юстиції в організації та забезпеченні функціонування системи правосуддя: автореф. дис. ... канд. юрид. наук: 12.00.10. Київ, 2007. 19 с.
} 
of state. The sole appointment and dismissal of the Minister of Justice (as in Belarus and Kazakhstan) in fact leads to his dependence on the Head of State. In our view, it is more constructive and democratic to involve in the order of appointment and dismissal of the Minister of Justice various higher bodies of state power, which will contribute not only to the balance of branches of government, but also to strengthening the independence of the Ministry of Justice and at the same time control over its activity to different entities. Considering the above, in the conditions of the parliamentary-presidential form of government, it is optimal to preserve the existing subordination of the system of justice bodies to the government and the procedure for appointing the Minister of Justice of Ukraine the parliament upon the submission of the Prime Minister.

The Institution of the Minister of Justice in foreign countries has a number of common features, which is manifested in the exercise of the traditional general powers to lead the work of the relevant ministry and other justice bodies, namely the organization of work, the division of responsibilities among subordinates, the definition of work plans, approval of provisions on structural units, issuance of mandatory orders, suspension and/or cancellation of decisions of subordinate bodies and units, etc.

In foreign countries, the system of justice, as a rule, is represented by the Ministry of Justice, its territorial bodies and other subordinate specialized bodies, whose activities are usually aimed at implementing state legal policy, improving the legislation, ensuring the functioning of the judicial system, enforcement of decisions of jurisdictions, administration and judiciary States in the courts, the organization of a practice of law and a notary.

The organization of the activity of justice bodies in foreign countries reveals, due to peculiarities of the state system, legal customs and other factors, significant differences in terms of the specific composition of the system of justice bodies and the degree of their independence, subordination to the Ministry of Justice of courts and prosecutor's offices, scope of tasks, forms of tasks, the Minister of Justice status, etc. The use of foreign experience in Ukraine is of primary importance for further decentralization of the activity of the bodies of justice, reduction of their administrative personnel and staff, streamlining the status of units of the state executive service and execution of criminal penalties, extension of powers to register legal acts and control their legal assistance, intensification of legal assistance and legal education of the population. 


\section{Ways of development of the administrative legislation that regulates the activity of the justice bodies of Ukraine}

The need for the development of the institute of justice is conditioned by the general processes of Ukraine's European integration, democratization and decentralization of public administration. It should be noted that some aspects of the improvement of the administrative and legal status of the bodies of justice of Ukraine have already been considered by such scientists as N.A. Zheleznyak, Kh.I. Kobotska (Dutka), I.I. Mykultsya, M.M. Priydak, S.R. Stanik, B.S. Stichinsky and others. At the same time, their scientific works have now partially lost their relevance, and they contain only some specific proposals for the development of the justice system of Ukraine, without reflecting a comprehensive approach to improving the administrative and legal regulation of their organization and activities of the current state bodies, legal and social-political realities of Ukraine. Therefore, in the context of increasing the efficiency and effectiveness of the functioning of the bodies of justice of Ukraine, the issues of improving the administrative and legal principles of their activity are also considered relevant.

First of all, it should be noted that the real improvement of the legal foundations of the organization and activity of the justice bodies of Ukraine should include not only the adoption of new and amendments to the current regulatory legal acts, but also the proper scientific and theoretical substantiation of the relevant elements of the administrative and legal status of the justice bodies. In addition, the directions and ways of improving the activities of the justice authorities should be determined solely on the basis of the urgent needs of the administration in the field of justice and within the general course of the internal policy of the state, while taking into account the existing organizational, human and material resources, peculiarities of the state system and the legal system of Ukraine, as well as positive foreign experience of functioning of justice bodies. An integral part of the process of improving the status of the justice bodies of Ukraine should be not only updating the administrative and legal bases, but also ensuring their practical implementation, real compliance and implementation in the activity of the justice bodies ${ }^{26}$.

The complexity, validity and consistency of improvement of the Institute of Justice of Ukraine are directly related to the preparation and approval at the government level of the relevant Concept of development

${ }^{26}$ Предместніков О. Г. Пріоритетні напрями подальшого вдосконалення державного управління під час проведення адміністративної реформи в Україні. Правові новели. 2014. № 1. C. 49-54. 
of the system of justice of Ukraine. Substantially, the Concept should clearly define not only the general goals and vectors of reform of the justice bodies of Ukraine, but also all the necessary legislative and organizational measures to improve their organization and activities, the timeframe for implementation of such measures and responsible bodies/persons.

A similar proposal was made by N.A. Zheleznyak on the advisability of adopting the Justice Reform Concept, in particular as part of the State Legal Policy Concept, the Judicial Reform Concept, or the Administrative Reform Concept $^{27,28}$. As for us, the Concept of development of the system of justice bodies, as one of the basic subsystems of public authorities in Ukraine, should be a separate comprehensive, professional and specific document, which at the same time will be consistent with all other concepts, programs and plans for the development of society, the state and law.

As a key measure to improve the administrative and legal foundations of the functioning of the justice system of Ukraine and to ensure greater legality and efficiency of their activity, we consider increasing the level of legislative regulation of their status and streamlining by-laws on the functioning of the justice bodies.

Increasing the level of legislative regulation of the status of the justice bodies of Ukraine necessitates the revision and streamlining of the existing array of by-laws and regulations concerning the justice bodies. Constructive is also an amalgamation of by-laws regulating various aspects of one line of activity of the justice bodies of Ukraine. The same applies to the by-laws that regulate the substantially homogeneous activity of the justice bodies in their various areas of competence. Optimization of the by-law regulation of the status of justice bodies of Ukraine will facilitate simplification and streamlining of their activity, provide integrity and accuracy of regulation will identify and eliminate legal conflicts, loopholes and duplicate rules.

A key measure of development of the bodies of Institute of Justice of Ukraine is a clear legal definition of the status and composition of their system, which will reflect a specific approach to understanding their nature and essence. One of the starting points of the status of the bodies of justice of Ukraine is their separation from the judiciary and the prosecutor's

27 Железняк Н. А. Правові та організаційні форми діяльності Міністерства юстиції України у здійсненні державної правової політики (теоретичні та практичні питання): дис. ... канд. юрид. наук: 12.00.07. Київ, 2004. С. 170, 171.

${ }^{28}$ Железняк Н. А. Реформування органів юстиції в контексті реалізації державної правової політики та проведення адміністративної реформи в Україні. Наукові записки НаУKMA. 2003. Т. 22. Ч. 2. C. 226-230. 
office. Notaries, lawyers, court experts, arbitration managers, as well as any other subordinate officials, enterprises, institutions and organizations cannot be designated as bodies of justice, since they do not directly exercise state-power organizational and administrative powers in the field of justice.

Only the Ministry of Justice of Ukraine and its territorial bodies should be included in the system of justice bodies of Ukraine. At the same time, it should be emphasized that the central bodies of executive power, whose activities are directed and coordinated by the Minister of Justice of Ukraine, are not themselves bodies of justice, in particular, this concerns the State Archival Service of Ukraine, whose activity according to the Decree of the Cabinet of Ministers of Ukraine dated 21.10.2015 No. $870^{29}$ is not fulfilled in the field of justice, but in the field of archival affairs and record keeping.

Improving the status of the main territorial administrations of justice should, as a matter of priority, involve streamlining their relations with local state administrations, in particular with regard to settling the principles of joint activity and law-making, forms and content of coordination and control by heads of local state administrations, as well as approving their plans of work of the main territorial administrations. We should also note the need to eliminate the gaps in the regulation of the status of the Main Territorial Administration of Justice in the city of Sevastopol, in the absence of the relevant Law of Ukraine on the status of this city.

At the same time, in order to observe and protect the rights of citizens, a more detailed legislative regulation of the peculiarities of the status and rules of work of territorial bodies of the Ministry of Justice of Ukraine in connection with the temporary occupation of the territory of the Autonomous Republic of Crimea and the city of Sevastopol and the conduct of anti-terrorist operations in some areas of Donetsk and Luhansk regions is more relevant.

Administrative and legal regulation of the activity of the bodies of justice of Ukraine should include the consolidation of their status as a whole and separate subsystem of bodies of executive power (state administration), characterized by subordination of the government, common purpose of activity, hierarchy and centrality in relation to the Ministry of Justice of Ukraine. The Ministry of Justice of Ukraine, being the leading central body of executive power on issues of implementation

29 Про затвердження Положення про Державну архівну службу України: постанова Кабінету Міністрів України від 21.10.2015 № 870. Офіиійний вісник України. 2015. № 88. Ст. 2930. 
and ensuring the formation of state legal policy, is the governing body of the system of justice bodies. At the same time, if the given status of the Ministry of Justice of Ukraine is somehow reflected in normative legal acts, the status of its territorial bodies in the system of bodies of executive power is not clearly stated. In this regard, we propose to define the territorial bodies of the Ministry of Justice of Ukraine as the leading local executive authorities on the implementation of relevant state policy.

The legal definition of the purpose of the activity of the bodies of justice is crucial not only for a proper understanding of their nature and vectors of development, but also for ensuring the purposefulness of the activity of the bodies of justice, and full consistency of their purpose, tasks, functions and powers. The current administrative and legal principles of the activity of the bodies of justice of Ukraine do not substantially fix the principles of their functioning, which can only be indirectly established on the basis of the general legislation on the status of executive bodies and other state bodies. We must disagree with this approach, since the principles embody conceptual frameworks that reflect the leading political and legal ideas and values regarding the nature and rules of the organization and operation of justice bodies. A clear formulation and real implementation of the principles is a necessary prerequisite for the legitimate and effective operation of the justice authorities, their rational organization, stability and consistency of the institution building in Ukraine. Among the basic principles that should not just be listed in the relevant law on the organs of justice, but really be embodied in its provisions, first of all, are the principles of the rule of law (including the law and respect for the rights and interests of citizens, legal persons, society and state), political, religious and other impartiality, professionalism, service to the Ukrainian people, continuity, transparency, accountability, responsibility, interaction, unity, systematic and others.

It should be noted that the improvement of the activity of the justice bodies of Ukraine in the current realities should largely involve bringing their tasks and powers in line with the actual needs of modernization, democratization, liberalization, decentralization and simplification of administration in the field of justice, introduction of a positive European experience. A comprehensive legislative regulation of the powers of the justice authorities will ensure the stability of their competence and impede the exercise of their non-judicial powers; grouping of specific powers according to the directions of activity of justice bodies will express conformity of their tasks and powers; securing the powers of the justice authorities in their specific units will ensure consistency of competence 
and structure; and the systematic nature of the Ukrainian justice authorities must be based on the full consistency of the competence of the Ministry of Justice of Ukraine and its territorial bodies.

At the level with the purpose of activity, tasks and powers, an integral element of the status of the bodies of justice of Ukraine are their functions, which at the same time remain normatively unregulated. The precise legal definition of the functions of the bodies of justice, their separation from the tasks and ensuring consistency with the powers is a necessary prerequisite for the integrity of the status and orderliness of the activity of the justice bodies of Ukraine. Among the main functions of the bodies of justice can be distinguished rulemaking, control, constituent, law enforcement, organizational, managerial and coordination, registration, representative, analytical and other functions.

The leading task of the Ministry of Justice of Ukraine is to ensure the formation and implementation of state legal policy, which is directly related to the development of the legal system of Ukraine, improving the rulemaking of public authorities, updating and eliminating shortcomings of national legislation. In this regard, in the framework of ensuring successful European integration of Ukraine, we consider it possible and expedient to actively involve the Ministry of Justice of Ukraine to work on the adaptation of the legislation of Ukraine to the EU legislation, for example, to carry out (previously carried out) examination of draft regulatory acts for their compliance with the acquis communautaire. Ch.I. Kobatska brings attention to the appropriateness of intensifying the participation of the Ministry of Justice of Ukraine in the implementation of Ukraine's European integration policy ${ }^{30}$.

The more effective implementation of the state legal policy by the bodies of justice, the coherence and improvement of the quality and legality of the rulemaking, as well as the observance of the rights and interests of citizens will be facilitated by the extension of the powers of the state registration justice to all normative legal acts of the state authorities and local self-government bodies; carrying out legal expertise on not only drafts of relevant legal acts, but also existing acts with the right to initiate their amendment and/or cancellation; compulsory examination by the Ministry of Justice of Ukraine of draft laws concerning its subjects; intensification of control of rulemaking of other executive bodies, etc.

\footnotetext{
${ }^{30}$ Кобацька Х. І. Порівняльно-правова характеристика центральних органів виконавчої влади у сфері юстиції: європейська традиція та вітчизняна практика: автореф. дис. ... канд. юрид. наук: 12.00.01. Київ, 2017. С. 4.
} 
The implementation of various specialized legal examinations by the justice authorities (legal examination within the framework of state registration of acts, gender-legal and anti-corruption expertise, etc.) determines a large number of unregulated by-laws. Therefore, in order to eliminate duplication, gaps and disagreements in regulating the procedure for conducting relevant legal expertise by the bodies of justice, it is first of all necessary to establish a single comprehensive regulation of the procedure and timing of initiation and conduct of legal expertise, as well as its clear legal consequences. In addition, the current powers of the Ministry of Justice of Ukraine to conduct legal expertise should be aligned with the regulatory procedures for the preparation, review and adoption of laws of Ukraine and acts of the Verkhovna Rada of the Autonomous Republic of Crimea.

To date, a large part of the powers of the justice bodies in the field of state registration have been delegated to local governments and notaries, which not only significantly relieves the activity of the justice bodies of Ukraine, but also provides accessibility for citizens of the relevant administrative services. R.V. Budetskyy ${ }^{31}$ also agrees with the decentralization of the administration of justice and emphasizes the need to delegate some of the managerial powers to the local authorities and nongovernmental entities. For this reason, in order to ensure the legal and proper fulfillment of such registration powers, the activities of the justice authorities should focus on continuous thorough monitoring of the work of state registration entities, their accreditation and the provision of comprehensive methodological assistance, and ensuring the high professional level of state registrars. Improving the activities of the justice sector in the field of justice should also include continuing the current practice of simplifying and speeding up state registration procedures (such as marriage) and the development of relevant electronic services ("Online House of Justice").

Participation in the legal education of the population is a promising area of improvement of the activity of justice bodies. Overcoming formalism (first of all by specifying powers and strengthening the control of their enforcement) and intensifying the comprehensive implementation by law enforcement agencies of various real and effective law enforcement measures (including via the Internet, television, radio, periodicals, public events, etc.) contribute to the development of Ukraine's civil society,

\footnotetext{
${ }^{31}$ Будецький Р. В. Міністерство юстиції України: до проблеми визначення адміністративно-правового статусу. Юрист України. 2014. № 3. С. 33, 34.
} 
raising the level of citizens' legal culture, implementation and protection of their rights.

At the same time, the activity of justice bodies in the field of providing free legal aid is also of great importance, which creates (in particular by setting up appropriate centers and bureaus on the basis of liquidated district justice bodies) conditions for the provision of accessible legal services aimed at ensuring the realization of citizens' rights and their protection and recovery. At present, the competence of the Ministry of Justice of Ukraine in this area is determined only in general terms, and therefore, given the status of justice bodies as leading subjects of the implementation of state legal policy, it is appropriate to consider a complex assignment of normative, coordinating, organizational and other powers in the sphere of providing free of charge legal assistance. The current solution in this area requires the provision of branch offices and free legal aid centers and bureaus, as well as staffing them with really qualified staff, involving highly-qualified lawyers to provide legal aid.

The structural organization and competence of the Ukrainian justice authorities must also be consistent with the number of their staff. As we have already noted, in the context of the elimination of district level justice bodies and integration into the system of justice units of state registration units, state executive service and execution of criminal penalties and probation, the staffing of justice bodies generally corresponds to the scope of their powers and number of subdivisions. At the same time, taking into account foreign experience and in order to save state funding, it is possible to further systematically reduce the number of employees of justice by eliminating duplicate units, redistribution of powers and staff, reducing the administrative apparatus, stimulating and improving the efficiency of employees. Another aspect of improving the activity of the justice bodies is the need to ensure a high professional level of their employees, effective counteraction to corruption and overcoming the problem of significant staff turnover, which among other things requires the enhancement of the authority of the justice bodies, increasing their legal and social guarantees of their employees. In order to overcome staff turnover in the bodies of justice I.I. Mykultsya ${ }^{32}$ also draws attention to the need to provide mentoring for newly recruited employees, to balance the workload for each employee, to increase the requirements for their work, bonuses depending on the performance indicators, proper equipment of the workplace, ensuring a healthy microclimate in the team, etc.

\footnotetext{
${ }^{32}$ Микульця I. І. Адміністративно-правовий статус органів юстиції України: дис. ... канд. юрид. наук: 12.00.07. Харків, 2014. С. 167.
} 
Thus, the improvement of administrative and legal foundations of the activity of the bodies of justice of Ukraine should have a proper scientific and theoretical substantiation, be all-embracing, comprehensive and consistent, providing for the constitutional consolidation of the status of the bodies of justice of Ukraine, adoption of a profile detailed Law of Ukraine, updating of other legislative acts, coordination and harmonization of legal acts on the issues of organization and activity of the justice bodies of Ukraine, ensuring real compliance and enforcement in their activities and applicable law.

\section{CONCLUSIONS}

The bodies of justice are indispensable components of the state apparatus of each state, which are responsible for the formulation and implementation of its legal policy, the establishment of the rule of law, and for the proper functioning of the jurisdictions and related entities. Despite the common purpose of their activities, the status, composition, competence and organization of the activities of justice bodies in different countries differ significantly, that is conditioned by the peculiarities of their legal system, constitutional order, legal traditions and the state of social development.

Improvement of the administrative and legal foundations of the activity of the bodies of justice of Ukraine should have proper scientific and theoretical substantiation, be comprehensive, all-embracing and consistent, carried out on the basis of urgent needs of management in the field of justice, within the course of the state domestic policy and taking into account the available organizational and financial resources, especially the state system and legal system of Ukraine, as well as positive foreign experience. The key vectors for the development of the justice bodies of Ukraine should be optimization and simplification of their organization, reduction of the administrative apparatus and staff, streamlining of the status of the units of the state executive service and execution of criminal penalties, application of modern progressive approaches to the fulfillment of tasks, decentralization of activities and ensuring priority in its observance and implementation of rights of citizens.

The updating of the legal bases for the organization and activity of the justice bodies of Ukraine is first and foremost related to the preparation and approval by the Government of the Concept of development of the justice bodies of Ukraine. The development of administrative and legal regulation of the activity of the bodies of justice of Ukraine requires the constitutional consolidation of the status of the bodies of justice of 
Ukraine, improvement of legislative acts, approval of the Regulations of activity of the bodies of justice and unified Regulations on their subdivisions, intensification of interagency regulation, harmonization and regulation of subordinate legal acts bodies of justice of Ukraine. An integral part of such improvement should be not only the updating of administrative and legal bases, but also ensuring their practical implementation, actual adherence and implementation in the activity of the justice bodies of Ukraine.

\section{SUMMARY}

It is stated that effective implementation of legal and non-legal forms of activity of the bodies of justice of Ukraine depends on the delimitation and coherence of legal and non-legal forms of activity, simplification of unreasonably complicated procedure of implementation of certain legal forms of activity, prevention of formalism in the implementation of forms of activity, ensuring compliance of the legal consequences of the actions of the justice bodies of Ukraine with their tasks and powers.

It is established that in foreign countries the system of justice bodies, as a rule, consists of the Ministry of Justice, its territorial bodies and other subordinate bodies, whose activity is aimed at the implementation of state legal policy, improvement of legislation, ensuring the functioning of the judicial system, enforcement of judgments and penalties, representation of the state in the courts, organization of a legal practice and a notary public.

It is determined that the organization of justice bodies in foreign countries reveals significant differences in terms of the composition of the system of justice bodies and their degree of independence, accountability to the Ministry of Justice of courts and prosecutors, their scope of tasks, and the extent of their tasks, the status of the Minister of Justice, etc. In foreign countries, the judicial and law enforcement type of justice system has become widespread, while in Ukraine and in a number of other postSoviet countries, justice bodies are of the general law type.

Attention is drawn to the fact that the development of administrative legislation governing the activity of the justice authorities of Ukraine should be purposeful, comprehensive and scientifically substantiated, taking into account the current needs of the administration in the field of justice and positive experience of foreign countries. 


\section{REFERENCES}

1. Будецький Р. В. Міністерство юстиції України: до проблеми визначення адміністративно-правового статусу. Юрист України. 2014. № 3. С. 29-36.

2. Будецький Р. Особливості управління юстицією у Сполучених Штатах Америки: організаційно-правовий аспект. Вісник Національної академї правових наук України. 2014. № 3. С. 155-164.

3. Железняк Н. А. Реформування органів юстиції в контексті реалізації державної правової політики та проведення адміністративної реформи в Україні. Наукові записки НаУКМА. 2003. T. 22. Ч. 2. С. 226-230.

4. Железняк Н. А. Правові та організаційні форми діяльності Міністерства юстиції України у здійсненні державної правової політики (теоретичні та практичні питання): дис. ... канд. юрид. наук: 12.00.07. Київ, 2004. 258 с.

5. Кобацька X. I. Порівняльно-правова характеристика центральних органів виконавчої влади у сфері юстиції: європейська традиція та вітчизняна практика: автореф. дис. ... канд. юрид. наук: 12.00.01. Київ, 2017. 19 с.

6. Микульця I. I. Адміністративно-правовий статус органів юстиції України: дис. ... канд. юрид. наук: 12.00.07. Харків, 2014. 203 с.

7. О судоустройстве и статусе судей: кодекс Республики Беларусь от 29.06.2006 №139-3. Начиональный реестр правовых актов Республики Беларусь. 2006. № 107. Ст. 2/1236.

8. Об образовании Государственного комитета судебных экспертиз Республики Беларусь: указ Президента Республики Беларусь от 22.04.2013 № 202. Национальный реестр правовых актов Республики Беларусь. 2013. Ст. 1/14233.

9. Об органах юстиции: закон Республики Казахстан от 18.03.2002 № 304-II. Ведомости Парламента Республики Казахстан. 2002. № 6. Ст. 67.

10.Об организации и функционировании Министерства юстиции: постановление Правительства Республики Молдова от 03.10.2012 № 736. Monitorul Oficial. 2012. №. 212-215. Ст. 799.

11.Об утверждении Положения о Министерстве юстиции Республики Беларусь: постановление Совета Министров Республики Беларусь от 31.10.2001 № 1605. Национальный реестр правовых актов Республики Беларусь.2001. № 107. Ст. 5/9385.

12.Положение о главном управлении юстиции Минского областного исполнительного комитета: решение Минского 
областного исполнительного комитета от 09.03.2015 № 199/Минский областной исполнительный комітет. URL: http://minobljust.gov.by/ ru/polojenie (дата звернення: 17.12.2016).

13. Предместніков О. Г. Пріоритетні напрями подальшого вдосконалення державного управління під час проведення адміністративної реформи в Україні. Правові новели. 2014. № 1. С. 49-54.

14.Про затвердження Положення про Державну архівну службу України: постанова Кабінету Міністрів України від 21.10.2015 № 870. Офіиійний вісник України. 2015. № 88. Ст. 2930.

15. Сазанов С. В., Могилёва И. Ю. Организация структуры органов принудительного исполнения Финляндской Республики. Юридический мир. 2010. № 5. С. 37-39.

16. Структура главного управления юстиции Минского областного исполнительного комитета: распоряжение председателя Минского областного испонительного комитета от 25.04.2013 № 90p / Минский областной исполнительный комитет. URL: http://minobljust.gov.by/ dadvfiles/000127_682722_struktura_gyu.doc (дата звернення: 17.12.2016).

17. Федькович О. В. Роль органів юстиції в організації та забезпеченні функціонування системи правосуддя: автореф. дис. ... канд. юрид. наук: 12.00.10. Київ, 2007. 19 с.

18. Чумак О. О. Практика організації діяльності органів примусового виконання рішень іноземних держав. Форум права. 2011. № 4. C. 814, 815. URL: http://nbuv.gov.ua/j-pdf/FP_index.htm_ 2011_4_133.pdf (дата звернення: 21.12.2016).

19. Aufgaben und Organisation Ministerium / Das Bundesministerium der Justiz und für Verbraucherschutz. URL: http://www.bmjv.de/DE/ Ministerium/Aufgaben Organisation/AufgabenOrganisation_node.html (дата звернення: 17.12.2016).

20. Organisation / Die Österreichische Justiz. URL: https://www.justiz.gv.at/web2013/home/ministerium/organisation 8ab4a8 a422985de30122a91a6504629f.de.html (дата звернення: 18.12.2016).

\section{Information about the author: Predmestnikov O. H.,}

Doctor of Law Sciences, Associate Professor, Professor at the Department of Professional and Special Disciplines, Kherson Faculty of Odessa State University of Internal Affairs 1, Fonvizina str., Kherson, 73000, Ukraine 